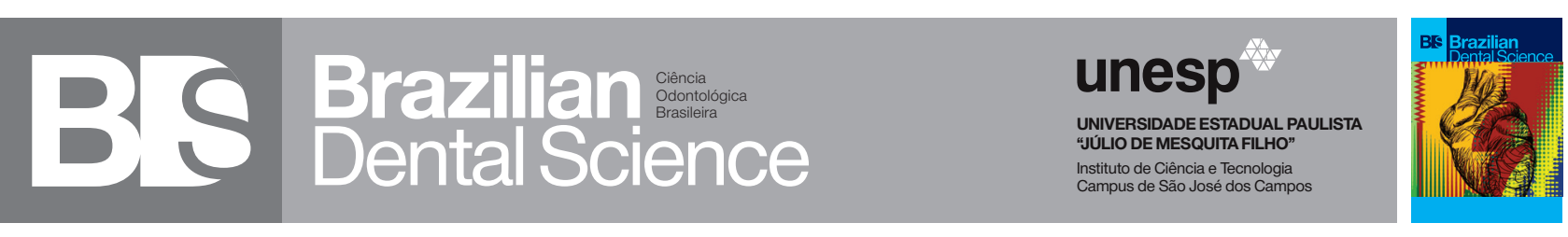

\title{
Effect of different surface treatments on the ceramic veneer surface: morphological analysis
}

\author{
Efeito de diferentes tratamentos na superfície da cerâmica de revestimento: análise morfológica
}

Karen Cristina ARCHANGELO ${ }^{1}$, Tabata Prado SATO ${ }^{1}$, Marcela Moreira PENTEADO ${ }^{1}$, Edwin Fernando Ruiz CONTRERAS ${ }^{2}$, Alexandre Luiz Souto BORGES ${ }^{1}$, Giovani de Oliveira CORRÊA ${ }^{2}$

1 - São Paulo State University (Unesp) - Institute of Science and Technology - São José dos Campos - Department of Dental Materials and Prosthodontics - SP - Brazil.

2 - Londrina State University - Londrina - Brazil.

\section{ABSTRACT}

Objective: The aim of this study was to evaluate the effect of different surface clinical treatments on the roughness (Ra) of a lithium disilicate ceramic veneer. Material and Methods: Forty-eight lithium disilicate discs with ceramic veneer and glaze layer were manufactured and distributed into six groups $(n=8)$ according to the surface treatment performed: G1, glaze layer (control group); G2, diamond bur 4138F; G3, diamond bur 4138F + 4138FF; G4, diamond bur $4138 \mathrm{~F}+$ new glaze layer; G5, diamond bur 4138F + ceramic polishing kit; G6, diamond bur 4138F + rubber cup with diamond paste + felt with diamond paste. Surface Ra measurement ( $\mu \mathrm{m})$ was performed using a profilometer before and after surface treatments, and one specimen from each group was subjected to Scanning Electron Microscopy (SEM) after treatment. Two-way ANOVA and Tukey's test (5\%) were used for data analysis. Results: Group 2 $(3,00 \pm 0,61)^{\mathrm{b}}$ showed higher values of Ra, followed by Group $3(1,93 \pm 0,45)^{c}$, Group $6(1,56 \pm 0,22)$ ac, Group $5(1,14 \pm 0,68)^{\mathrm{a}}$ and Group $4(0,90 \pm$ $0,26)^{a}$. G4, G5 and G6 were not different between each other and control group $(1,11 \pm 0,21)^{\mathrm{a}}$. SEM imaging revealed surface smoothness in G1, G4 and G5, and presence of irregularities in G2, G3 and G6. Conclusion: it is possible to conclude that different surface clinical treatments influences the roughness of a lithium disilicate ceramic veneer.

\section{KEYWORDS}

Ceramics; Dental porcelain; Dental polishing.

\section{RESUMO}

Objetivo: o objetivo deste estudo foi avaliar o efeito de diferentes tratamentos clínicos de superfície na rugosidade (Ra) de uma cerâmica de cobertura de dissilicato de lítio. Material e Métodos: foram fabricados e distribuídos quarenta e oito discos de dissilicato de lítio com cerâmica de revestimento e vitrificação em seis grupos $(n=8)$ de acordo com o tratamento de superfície realizado: G1, camada vitrificada (control group); G2, ponta diamantada 4138F; G3, ponta diamantada 4138F + 4138FF; G4, ponta diamantada 4138F + nova camada vitrificada; G5, ponta diamantada $4138 \mathrm{~F}+$ kit de polimento cerâmico; G6, ponta diamantada $4138 \mathrm{~F}$ + taça de borracha com pasta diamantada + feltro com pasta diamantada. A análise da superfície Ra $(\mu \mathrm{m})$ foi realizada usando-se um perfilômetro antes e depois dos tratamentos de superfície, e uma amostra de cada grupo foi à Microscopia Eletrônica de Varredura (MEV) após o tratamento. Two-way ANOVA e o teste de Tukey (5\%) foram utilizados para análise de dados. Resultados: O Grupo $2(3,00 \pm 0,61)^{\mathrm{b}}$ apresentou valores mais altos de Ra, seguido do Grupo $3(1,93 \pm 0,45)$ c, Grupo $6(1,56 \pm 0,22)^{\text {ac }}$, Grupo $5(1,14 \pm 0,68)^{\text {a }}$ e Grupo $4(0,90 \pm 0,26)^{\mathrm{a}}$. G4, G5 e G6 não eram diferentes entre si e entre grupo de controle $(1,11 \pm 0,21)^{\text {a }}$. A imagem de MEV revelou suavidade da superfície em G1, G4 e G5, e presença de irregularidades em G2, G3 e G6. Conclusão: é possível concluir que diferentes tratamentos clínicos de superfície influenciam a rugosidade de uma cerâmica de revestimento de dissilicato de lítio.

\section{PALAVRAS-CHAVE}

Cerâmica; Porcelana Dentária; Polimento Dentário. 


\section{INTRODUCTION}

$\mathrm{T}$ he clinical use of metal-free ceramics has become routine practice in dentistry $[1,2]$. This is attributable to their favorable properties, such as biocompatibility, chemical resistance, reduced plaque accumulation and superior aesthetics [3], combined with high fracture resistance $[4,5]$.

Glass-ceramics are materials formed by the melting of a matrix that is crystallized and converted by an appropriate heat treatment process [6]. These materials are receiving substantial attention for clinical applications [7].

Of particular importance is the lithium disilicate ceramic (Li2Si2O5)[8], widely used due to its higher flexural strength and fracture toughness as compared with other types of glassceramics, such as leucite-based (KAlSi2O6), mica-based (KMg2,5Si4O10F2), fluorapatite (Ca5(PO4)3F) and leucite-apatite ceramics $[8,9]$. Increasing the crystalline content to $70 \%$ and refining the crystal size improved the flexural strength of this material to approximately 360 MPa.

Another important feature is the low refractive index of the crystals, which makes the material translucent enough to be used in monolithic aesthetic restorations or receive a ceramic veneer [10]. The coating material can be used on pressed-ceramic or CAD/CAM systems, and consists of a glass-ceramic with fluorapatite crystals, having a thermal expansion coefficient compatible with the infrastructural material [11].

The importance of a smooth surface is based on three factors: function, biologic compatibility and aesthetics [12]. Rough surfaces can decrease the flexural strength of the restoration material [13] and permit hard tissue abrasion of the antagonists of the restored tooth, consequently leading to wear, as the ceramic material is usually harder than the natural tooth [14].

Although dental ceramics have properties suitable for use as aesthetic restorations, finishing and polishing procedures are essential to achieve an adequate surface texture and light reflection [15]. Traditionally, the aesthetic finishing of ceramics surface is achieved by glazing [16].

Two glazing techniques are available: auto-glazing or self-glazing, in which the surface of the ceramic itself is allowed to melt at a high temperature (around $940^{\circ} \mathrm{C}$ ) to provide the glaze layer, and overglazing, which consists of application of a thin layer of low-fusing glass onto the ceramic surface, which is then fired at a lower temperature to obtain the glaze layer [14].

Furthermore, occlusal adjustments are sometimes necessary, and any adjusted should be reglazed or subjected to a sequence of polishing $[17,18]$.

The surface roughness also could provide an initial bacterial adhesion [19,20], leading to accumulation of biofilm and making the oral environment susceptible to infections and increased incidence of caries [20,21].

Several methods of finishing systems on ceramic roughness have been compared [22, 23]. Different finishing/polishing protocols and products are available, such as sandpapers and pastes containing diamond or aluminium oxide particles, which can be used with brush or felt disc $[15,24,25]$.

Many studies reported that polishing systems promote smoother surfaces than glazing $[26,27]$. Others, however, suggested that polishing is unable to promote smooth surfaces as glazing process $[14,16,23]$.

In this sense, the purpose of this study was to evaluate and to compare morphological aspects of treatment procedures on the surface 
of a lithium disilicate ceramic veneer. And the hypothesis of this study was that different surface clinical treatments influences the roughness of a lithium disilicate ceramic veneer.

\section{METHODS AND MATERIALS}

48 red self-curing acrylic (Kota Imports, São Paulo, São Paulo, Brazil) disc matrix, 1.5 height and $6 \mathrm{~mm}$ diameter, were placed in an investment ring and in a Programat EP 5000 press furnace (IvoclarVivadent, Schaan, Liechtenstein) for heat-pressing of e.max Press ceramic (Ivoclar Vivadent, Schaan, Liechtenstein) in accordance with manufacturer instructions (Table 1). After cooling to room temperature, the investment ring was separated with a silicon carbide disk, and the pressed ceramic divested by blasting with $80-\mu \mathrm{m}$ aluminium oxide particles (Asfer Indústria Química, São Caetano do Sul, São Paulo, Brazil) under 6 bar of pressure to remove the investment material completely. Finally, the sprue was cut off with a diamond disc and the attachment area finished with a Master Ceram grinding stone (Eurodental, São Paulo, São Paulo, Brazil) to obtain the pressed ceramic discs.

The resulting $1.5 \mathrm{~mm}$ discs were coated with e.max Ceram (Ivoclar Vivadent, Schaan, Liechtenstein) to a final thickness of $3.5 \mathrm{~mm}$. For this purpose, a second matrix was fabricated from silicone lab putty (Silicone Master, Talmax, Curitiba, Paraná, Brazil). This matrix (diameter $70 \mathrm{~mm}$, height $9 \mathrm{~mm}$ ) contained four orifices with a diameter of $6 \mathrm{~mm}$ and depth of $3.5 \mathrm{~mm}$ each. The orifices were coated with mineral oil (Nujol, Mantecorp, Rio de Janeiro, Rio de Janeiro, Brazil) and the discs inserted inside them. The chosen ceramic was shade transpa incisal 2, which was homogenized in a ceramic mixing tray with IPS e.max Ceram Build-Up liquid (Ivoclar Vivadent, Schaan, Liechtenstein) and applied with a brush. After all orifices had been filled, the discs were removed from the matrix, placed on a ceramic fiber blanket, and fired in a Programat P500 oven (Ivoclar Vivadent, Schaan, Liechtenstein), at an initial temperature of $403^{\circ} \mathrm{C}$, until the final temperature of $760^{\circ} \mathrm{Caccording}$ to manufacturer's instructions (Table 2). Due to contraction of the ceramic, a further two firings were performed, using the same procedure described above but to a final firing temperature of $750^{\circ} \mathrm{C}$, in view of the smaller volume of material. After these procedures, any irregularities present on the edges of the discs were removed with diamond burs and the discs were measured again to verify their dimensions. Then the glazing procedure was performed, in which e.max Ceram system (IvoclarVivadent, Schaan, Liechtenstein) glaze powder and liquid were combined in a porcelain mixing tray and the mixture was brushed onto the discs, which were then fired (Table 2).

The 48 specimens, were randomly divided into six groups $(n=8)$ using an online random number generator (random.org).

1) Group 1 (G1): control group - veneer ceramic with glaze layer.

2) Group 2 (G2): veneer ceramic with glaze layer. The specimens were abraded with a fine-grit diamond bur (4138F - KG Sorensen, Cotia, São Paulo, Brazil), run three times over the surface of the specimen under slight pressure, to remove the glaze layer.

3) Group 3 (G3): same procedure as G2, followed by finishing with an extra fine-grit diamond bur (4138FF - KG Sorensen, Cotia, São Paulo, Brazil), run three times over the surface of the specimen under slight pressure.

4) Group 4 (G4): same procedure as G2, followed by reglazing of the surface.

5) Group 5 (G5): same procedure as G2, followed by polishing with the OptraFine system (IvoclarVivadent, Schaan, Liechtenstein), using the disc-shaped polishers in decreasing order of grit (polisher F - light blue, followed by polisher P - dark blue), followed by polishing with a nylon brush saturated with 2-4 $\mu \mathrm{m}$ grit diamond 
polishing paste. Surfaces were polished for 30 seconds with each instrument, at low speed, moderate pressure, and under irrigation for the polishing discs.

6) Group 6 (G6): same procedure as G2, followed by polishing with rubber cup (Microdont, Socorro, São Paulo, Brazil) with extra-fine $(2-4 \mu \mathrm{m})$ diamond polishing paste (Diamond Excel, FGM, Brazil), followed by polishing with a felt disc (Diamond, FGM, Joinvile, Santa Catarina, Brazil) and the same polishing compound. Surfaces were polished for 30 seconds with each instrument while exerting moderate pressure.

All procedures were carried out by the same investigator. The diamond burs were discarded after four uses, rubber cups after every two specimens, and felt discs were used only once each. After each treatment, the specimens were rinsed with distilled water in an ultrasonic cleaner bath and dried with compressed air.

\section{Surface Roughness Testing}

The assessed roughness parameter was Ra (roughness average), and calculated with a Surftest SJ-400 portable profilometer (Mitutoyo America, Aurora, Illinois, USA), calibrated with a $0.8 \mathrm{~mm}$ cutoff filter and a total scan length of 2.4 $\mathrm{mm}$. Using diamond burs, three approximately equidistant points (distance of $\sim 120^{\circ}$ ) were demarcated on the edge of each specimen. One measurement was obtained at each point for a total of three measurements per specimen; these three values were then averaged to obtain the Ra. All specimens were measured by the same operator, before and after treatment.

\section{Scanning Electron Microscopy (SEM)}

One specimen from each group was prepared for high-resolution scanning electron microscopy (SEM), with the purpose of comparing SEM images to the Ra values obtained with the profilometer. Each disc was mounted with double-sided tape onto a stub and sputtercoated in a Bal-Tec SCD 050 sample coater (Bal-Tec, Balzers, Liechtenstein) with a $25 \mathrm{~nm}$ carbon layer, which is required for conduction of the electron beam. The prepared discs were then imaged in a Quanta 200 (Fei, Hillsboro, Oregon, USA) scanning electron microscope, set to 500x magnification, low-vacuum mode and $20 \mathrm{kV}$.

\section{Statistical Analysis}

After confirming the normality of data distribution with the Shapiro-Wilk test, results were analyzed by means of Two-way ANOVA and Tukey's multiple comparisons with a 95\% confidence level.

\section{RESULTS}

The surface treatments performed were statistically significant at the 5\% level. Before treatment, analyses showed no significant differences in Ra values among groups G1 to G6 (Figure 1).

After treatment, as shown in Figure 2, significant differences were found between the control group $(1.11 \pm 0.21)$ and groups G2 (3.00 \pm 0.61$)$ and G3 (1.93 \pm 0.45$)$, but no differences were found between the control group and G4 (new glaze layer) $(0.90 \pm 0.26)$, G5 (polishing kit) (1.14 \pm 0.68$)$, or G6 (rubber cup and felt with diamond paste) $(1.56 \pm 0.22)$. Group G2, in which specimens were abraded with a 4138F diamond bur, was significantly different from all other groups. Differences were found between G3 and G4 and between G3 and G5, but not between G3 and G6. Group G4, in which specimens were reglazed, was not significantly different from groups G1, G5 or G6, but was significantly different from the others. There were no statistical differences between Ra values in G5 and G6 (Table 3). Figure 3 
shows SEM micrographs of ceramic surfaces from each group. G1 (Figure 3A) represents the smoothest surface pattern on comparison with the other groups (Figures 3A through $3 \mathrm{~F}$ ), and is very similar to Figures $3 \mathrm{~B}$ and $3 \mathrm{C}$ in terms of surface homogeneity. Figures 3D and 3E shows surface irregularities. In G6 (Figure 3F), these irregularities still present, but in lower density.

Thus, ANOVA revealed that $\mathrm{Ra}$ values were influenced by the treatment type applied to the specimens (Table 3). SEM images showed the specimens surface homogeneity in the glaze layer, new glaze layer, polishing kit groups, and their differences on comparison with the other groups, that presented porous and irregular surfaces.

This was found even in polished groups with rubber cup, felt discs and diamond paste, although with decreased surface failures presence.

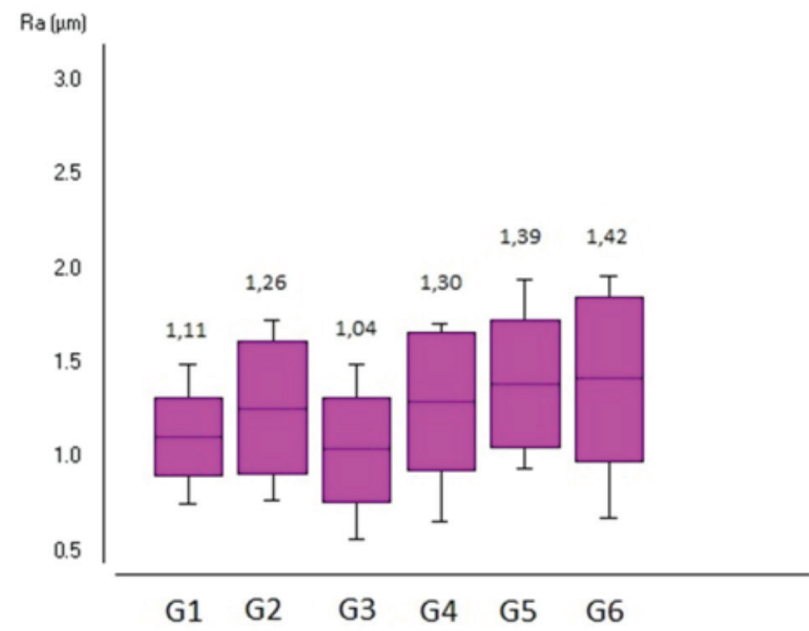

Figure 1 - Box plot of pre-treatment surface roughness (Ra) values, in $\mu \mathrm{m}$, in all six groups. Data expressed as mean and interquartile range. The mean is represented by the horizontal line within the box, and the range is represented by the strokes above and below it.

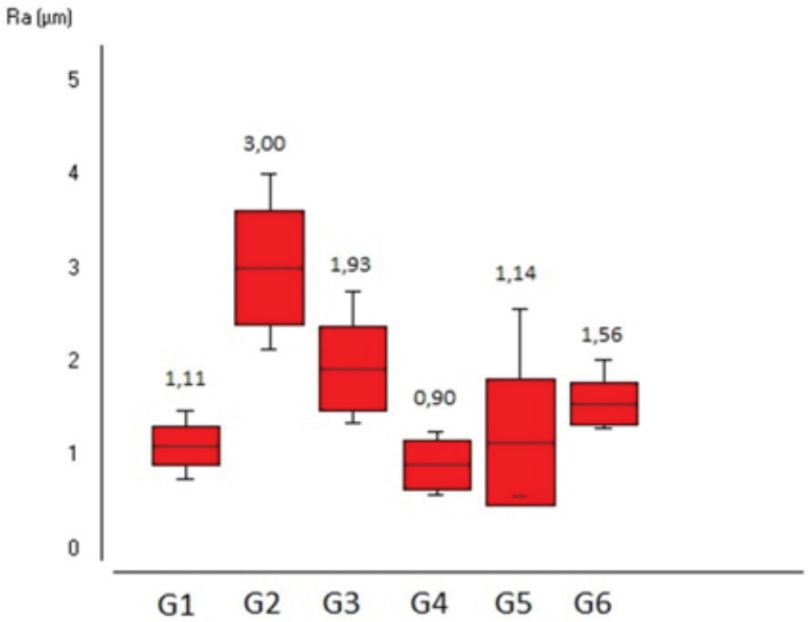

Figure 2 - Box plot of post-treatment surface roughness (Ra) values, in $\mu \mathrm{m}$, in all six groups. Data expressed as mean and interquartile range. The mean is represented by the horizontal line within the box, and the range is represented by the strokes above and below it.
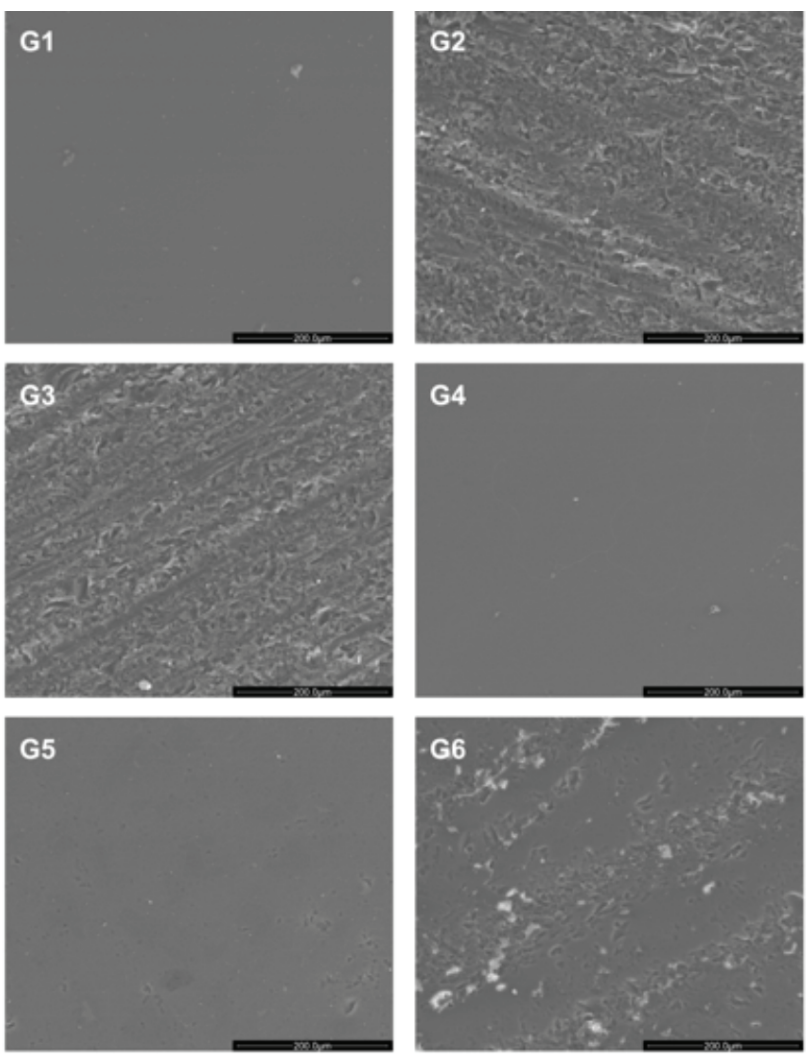

Figure 3 - SEM of all experimental groups. 


\section{DISCUSSION}

This study evaluated the effect of different treatment procedures on the surface of a lithium disilicate ceramic veneer, analyzing morphological aspects.

Glazing technique provides a smooth and bright surface [28] and the polishing abrasion provided rough surfaces that removes the glaze layer, exposing failures in the ceramic $[14,28]$.

Meanwhile, diamond burs are commercially available and widely known by clinicians, which makes their use for adjustment and finishing of ceramic restorations a ordinary practice [14], and this study demonstrated their poor efficiency for this purpose, producing high average roughness values and irregular surfaces, with pores and grooves, on SEM analysis (Figure 3).

Thus, additional treatment to promote acceptable surface smoothness is necessary. Furthermore, clinical adjustment of restorations could create subcritical defects that may grow into fractures, resulting in a stress concentration [29].

SEM analysis showed that the use of diamond burs for adjustment produced rough surfaces, whereas use of a commercial polishing system provided a clear improvement in the smoothness of the ceramic surface. Corroborating these results, another study demonstrated that ceramics polished with fine burs had higher average roughness values than specimens glazed or polished with extra fine burs [30].

In this context, an analysis of two ceramic systems, IPS Empress 2 (IvoclarVivadent) and In-Ceram/Vitadur Alfa (Vita-Zahnfabrik), showed that, after any adjustment to a ceramic restoration, the restoration should be reglazed or polished, which reduces Ra values [18], as seen in groups G4, G5 and G6 in the present study.
The use of an extra fine bur after wearing down with diamond bur 4138F in G3 led to improvement in Ra values, but no such improvement was visible on SEM analysis. Corroborating these findings, a study [31] observed that some polishing systems were effective in reducing the surface roughness of lithium disilicate ceramics, but a rubber point type was effective to re-establish an adequate superficial smoothness.

The re-glazing after surface adjustment was effective to promote smoothness surface in this study, as Ra values and with SEM showed.

Glaze system it is considered one of the most effective methods of ceramic surface treatment $[18,32]$ and is recommended a second round of glazing or polishing after clinical adjustment [33].

Furthermore, another study evaluated the effect of diamond burs and subsequent heat treatment on lithium disilicate ceramics, and concluded that burs produces flaws and cracks, with consequent flexural strength decrease, restored after heat treatment or re-glazing [34].

Adjustment with a fine bur, followed by rubber cup and felt disc with diamond paste, was effective reducing surface roughness values. The use of felt discs and diamond paste has been suggested as an effective method for ceramic surface polishing [34].

Based on comparative analysis of $\mathrm{Ra}$ values and SEM images, it is possible to infer that the methods which provide the greatest surface smoothness, with the least irregularity and porosity, are the original glaze layer, new glaze (after adjustment), and polishing with a commercially available kit.

From this, the hypothesis that different surface clinical treatments influences the roughness of a lithium disilicate ceramic veneer could be accepted. 


\section{CONCLUSION}

In view of the study findings, it is possible to conclude that different surface clinical treatments influences the roughness of a lithium disilicate ceramic veneer.

Therefore, fine and extra-fine diamond burs promote increased surface roughness, and should not be used to polish ceramic restorations. Glazing should only be replaced by appropriate polishing systems. Polishing with rubber cup and felt with diamond paste was not effective in producing a smooth surface. Glazing, re-glazing, and polishing with the OptraFine system are effective methods for polishing and finishing ceramics.

\section{REFERENCES}

1. Edelhoff D, Brix 0 . All-ceramic restorations in different indications: a case series. J Am Dent Assoc. 2011 Apr;142 Suppl 2:14S-9S

2. Fasbinder DJ, Dennison JB, Heys D, Neiva G. A clinical evaluation of chairside lithium disilicate CAD/CAM crowns. J Am Dent Assoc. 2010 Jun;141Suppl 2:10S-4S.

3. Etman MK, Woolford M. Three-year clinical evaluation of two ceramic crown systems: a preliminary study. J Prosthet Dent. 2010 Feb;103(2):80-90. doi: 10.1016/S0022-3913(10)60010-8.

4. StappertCF,AttW, Gerds T, Strub JR. Fracture resistance of different partialcoverage ceramic molar restorations: An in vitro investigation. J Am Dent Assoc. 2006 Apr;137(4):514-22.

5. SuputtamongkolK, Anusavice KJ, Suchatlampong C, Sithiamnuai P, Tulapornchai C. Clinical performance and wear characteristics of veneered lithia-disilicate-based ceramic crowns. Dent Mater. 2008 May;24(5):667-73. Epub2007 Aug 28

6. Hillig WB. Melt infiltration approach to ceramic matrix composites. Journal of the American Ceramic Society. 1988;71(2):96-9.

7. Yamamuro T.Clinical Application of Glass Ceramics: Biomechanics and Biomaterials in Orthopedics: Springer; 2016. p. 153-7.

8. Passia N, LehmannF,Freitag-Wolf S, Kern M. Tensile bond strength of different universal adhesive systems to lithium disilicate ceramic. J Am Dent Assoc. 2015 0ct;146(10):729-34. doi:101016/j.adaj.2015.04.008.

9. Huang S, Zhang B, Huang Z, Gao W, Cao P.Crystalline phase formation, microstructure and mechanical properties of a lithium disilicate glassceramic. J Mater Sci. 2013;48(1):251-7.

10. Lee B, Gadow R, Mitic V.Proceedings of the IV Advanced Ceramics and Applications Conference: Atlantis Press; 2017.

11. Giordano R, McLarenEA. Ceramics overview: classification by microstructure and processing methods. Compend Contin Educ Dent. 2010;31(9):682-4.

12. Yilmaz K, OzkanP.The methods for the generation of smoothness in dental ceramics. Compend Contin Educ Dent. 2010;31(1):30-2.

13. Fischer $H$, Schäfer M, Marx R. Effect of surface roughness on flexural strength of veneer ceramics. J Dent Res. 2003 Dec;82(12):972-5.
14. Aksoy G, Polat H, Polat M, Coskun G. Effect of various treatment and glazing (coating) techniques on the roughness and wettability of ceramic dental restorative surfaces. Colloids Surf B Biointerfaces. 2006 Dec 1;53(2):254-9. Epub2006 Sep 27.

15. Boaventura JMC, Nishida R, Elossais AA, Lima DM, Reis JMSN, Campos EA, et al. Effect finishing and polishing procedures on the surface roughness of IPS Empress 2 ceramic. Acta Odontol Scand. 2013 May-Jul;71(3-4):438-43. doi: 10.3109/00016357.2012.690570. Epub2012 Jun 25.

16. Tuncdemir AR, Dilber E, Kara HB, Ozturk AN. The effects of porcelain polishing techniques on the color and surface texture of different porcelain systems. Mater Sci Applications. 2012;3(05):294.

17. Hobkirk J,Psarros K. The influence of occlusal surface material on peak masticatory forces using osseointegrated implant-supported prostheses. Int J Oral Maxillofac Implants. 1992 Fall;7(3):345-52.

18. Al-Wahadni A. An in vitro investigation into the surface roughness of 2 glazed, unglazed, and refinished ceramic materials. Quintessence Int. 2006 Apr;37(4):311-7.

19. Yu P,Wang C, Zhou J, Jiang L, Xue J, LiW. Influence of Surface Properties on Adhesion Forces and Attachment of Streptococcus mutans to Zirconia In Vitro. Biomed Res Int. 2016;2016:8901253. Epub2016 Nov 15.

20. VoDT,ArolaD, RombergE,Driscoll CF, Jabra-Rizk MA, MasriR. Adherence of Streptococcus mutans on lithium disilicate porcelain specimens. JProsthetDent. 2015 Nov;114(5):696-701. doi:10.1016/j.prosdent2015.06.017.Epub2015 Sep 16.

21. Kawai K, Urano M, Ebisu S. Effect of surface roughness of porcelain on adhesion of bacteria and their synthesizing glucans. J Prosthet Dent. 2000 Jun;83(6):664-7.

22. Martínez-Gomis J, Bizar J, Anglada JM, Samsó J, Peraire M. Comparative evaluation of four finishing systems on one ceramic surface. Int J Prosthodont. 2003Jan-Feb;16(1):74-7.

23. Patterson C, McLundie A, Stirrups D, Taylor W. Refinishing of porcelain by using a refinishing kit. J ProsthetDent. 1991Mar;65(3):383-8.

24. Goldstein R. Finishing of composites and laminates. Dent Clin North Am. 1989 Apr;33(2):305-18,210-9.

25. Raimondo RL, Richardson JT, Wiedner B. Polished versus autoglazed dental porcelain. JProsthet Dent. 1990 Nov;64(5):553-7.

26. Wright MD, Masri R, Driscoll CF, Romberg E, Thompson GA, Runyan DA. Comparison of three systems for the polishing of an ultra-low fusing dental porcelain. The Journal of prosthetic dentistry. 2004;92(5):486-90.

27. Albakry M, Guazzato M, Swain MV. Effect of sandblasting, grinding, polishing and glazing on the flexural strength of two pressable all-ceramic dental materials. Journal of dentistry. 2004;32(2):91-9.

28. Brunot-Gohin C,Duval J-L, Azogui E-E, Jannetta R, Pezron I, Laurent-Maquin D, et al. Soft tissue adhesion of polished versus glazed lithium disilicate ceramic for dental applications. Dental Materials. 2013;29(9):e205-e12.

29. Amer R, Kürklü D, KateebE, Seghi RR. Three-body wear potential of dental yttrium-stabilized zirconia ceramic after grinding, polishing, and glazing treatments. The Journal of prosthetic dentistry. 2014;112(5):1151-5.

30. De Jager N, Feilzer A, Davidson C. The influence of surface roughness on porcelain strength. Dental Materials. 2000;16(6):381-8.

31. Silva TMd, Salvia ACRD, Carvalho RFd, Silva EGd, Pagani C. Effects of Different Polishing Protocols on Lithium Disilicate Ceramics. Brazilian Dental Journal. 2015:26:478-83.

32. Bottino MC, Valandro LF, Kantorski KZ, Bressiani JC, Bottino MA. Polishing methods of an alumina-reinforced feldspar ceramic. Brazilian dental journal. 2006;17(4):285-9. 
33. Fuzzi M,ZaccheroniZ, Vallania G. Scanning electron microscopy and profilometer evaluation of glazed and polished dental porcelain. International Journal of Prosthodontics. 1996;9(5).
34. OhS-C,Dong J-K, Lüthy H, Schärer P.Strength and microstructure of IPS Empress 2 glass-ceramic after different treatments. International Journal of Prosthodontics. 2000;13(6).

\section{Tabata Prado Sato}

(Corresponding address)

Av. Dr. Eng.Francisco Jose Longo, 777, Jd. Sao Dimas

Sao Jose dos Campos, Brazil

Date submitted: 2017 Dec 19

Email: tabata.sato@ict.unesp.br 